\title{
Evaluation of microbial survival post-incidence on fresh Mozzarella cheese ${ }^{1}$
}

\author{
Balasubramanian Ganesan, ${ }^{2}$ David A. Irish, Carl Brothersen, and Donald J. McMahon \\ Dairy Technology and Innovation Laboratory, Western Dairy Center, Department of Nutrition, Dietetics and Food Sciences, \\ Utah State University, Logan 84322
}

\section{ABSTRACT}

Commercial fresh Mozzarella cheese is made by direct acidification and is stored dry or in water without salt addition. The cheese has a shelf life of $6 \mathrm{wk}$, but usually develops an off-flavor and loses textural integrity by 4 wk, potentially due to the lack of salt and high moisture that allow the outgrowth of undesirable bacteria. To understand how microbial incidence affects cheese quality and how incident pathogen-related bacteria are limited by salt level during refrigerated storage, we made fresh Mozzarella cheese with high $(2 \%)$ and low $(0.5 \%)$ salt. The high-salt cheese was packaged and stored dry. The low-salt cheese was packaged and stored either dry or in $0.5 \%$ salt brine. One portion of cheeses was evaluated for surviving incident microbes by aerobic plate counts, coliform counts, and psychrophilic bacterial counts, of which coliforms and psychrophiles were not detected over 9 wk. Aerobic plate counts remained at 100 to 300 cfu/g up to 2 wk but increased by 1,000- to 10,000-fold between 4 and $6 \mathrm{wk}$ at all salt levels and storage conditions. Other portions of cheeses were inoculated with either Escherichia coli or Enterococcus faecalis, both of which increased by 100 -fold over $90 \mathrm{~d}$ of storage. Interestingly, E. coli added to the cheese brine first grew in the brine by 100 -fold before attaching to the cheese, whereas Ent. faecalis attached to the cheese within $24 \mathrm{~h}$ and grew only on the cheese. We conclude that incident bacteria, even from similar environments, may attach to cheese curd and survive differently in fresh Mozzarella cheese than in brine. Overall, $2 \%$ salt was insufficient to control bacterial growth, and slow-growing, cold- and salt-tolerant bacteria may survive and spoil fresh Mozzarella cheese.

Key words: fresh mozzarella, Escherichia coli, Enterococcus, microbial survival

\footnotetext{
Received January 30, 2012.

Accepted August 17, 2012.

${ }^{1}$ This study was funded by the Dairy Research Institute and administered by Dairy Management Inc. (Rosemont, IL).

${ }^{2}$ Corresponding author: g.balsu@usu.edu
}

\section{INTRODUCTION}

Fresh Mozzarella cheese is a popular cheese in the US market (USDA, 2006) and is commonly used in salads and for direct consumption as fresh cheese. Acceptable fresh Mozzarella cheese has a flavor that closely resembles fresh milk, with a creamy sensation. Fresh Mozzarella cheese is made by direct acidification with citric acid or white vinegar to lower $\mathrm{pH}$ (Dave et al., 2003), as opposed to starter addition in other commercial pasta filata cheese types (USDA, 1980; Anon, 1983; Pastorino et al., 2002), and is stored dry or in water without salt addition.

Refrigerated storage and low $\mathrm{pH}(<5.4)$ provide the only deterrents to the growth of unwanted organisms during fresh Mozzarella cheese storage. Current shelf life of commercial fresh Mozzarella cheeses is 21 to 30 $\mathrm{d}$, although the cheese usually develops off-flavor and loses its textural integrity within that time (USDA, 1980). The short shelf life of fresh Mozzarella cheese compared with other pasta filata cheeses may be attributed to the absence of salt, any added lactic acid bacteria (LAB; Fischer and Megevand, 2006) that produce bacteriocins, and the high moisture in curd (approximately 60\%) that promotes unwanted bacterial growth and metabolic activity (Anon, 1983; Deeprose, 1996). Weakening of texture during this short shelf life is due to proteolysis (Dave et al., 2003), potentially from incident bacteria or their enzymes.

Milk used for cheese manufacture is required to be pasteurized at $72^{\circ} \mathrm{C}$ for $15 \mathrm{~s}$ or its equivalent, according to US Food and Drug Administration (FDA) regulations (FDA, 2011), which destroys most common pathogenic or spoilage bacteria. However, heat-resistant pathogenic and spoilage bacteria may be present in raw milk or equipment surfaces, and even non-heatresistant bacteria may gain access during cheese manufacture (Kikuchi et al., 1996). The presence of these bacteria is detrimental to cheese shelf life and quality (el-Gazzar and Marth, 1992; Schlesser et al., 2006). Either the cells or their enzymes survive underpasteurization or are resistant to standard pasteurization. For example, even though Pseudomonas present in raw milk is destroyed by HTST pasteurization, it produces heat- 
stable lipases (Koka and Weimer, 2001) and proteases (Koka and Weimer, 2000) that affect cheese flavor and texture (Cabrini and Neviani, 1983). Similarly, the Stx2 shiga toxin produced by enterohemorrhagic Escherichia coli $\mathrm{O} 157: \mathrm{H} 7$ is resistant to milk pasteurization and other equivalent heat treatments and is destroyed only by $100^{\circ} \mathrm{C}$ for 5 min (Rasooly and Do, 2010). Although the presence of Stx2 in foods is not known to cause illness upon direct consumption, Stx2 directly fed to mice caused mortality (Rasooly et al., 2010), and may hence be a human health risk. Other incident bacteria such as Staphylococcus aureus produce enterotoxins in foods that cause emetic illness upon consumption, or the foods may contain surviving enterotoxigenic $E$. coli that produce toxins in the intestine and cause diarrhea (Weeratna and Doyle, 1991; Bowen and Henning, 1994; Delbès et al., 2007; Zhang and Sack, 2012). Fecal streptococci also enter through routes similar to E. coli and are tolerant to $6.5 \%$ salt and both high and low temperatures $\left(45\right.$ and $10^{\circ} \mathrm{C}$; Bissonnette et al., 1980; Morea et al., 1999). Listeria is also a salt- and coldtolerant pathogen commonly found in semihard and soft cheeses (FDA, 2009a,b, 2010b). Process conditions such as higher Mozzarella cooking temperatures (66 to $77^{\circ} \mathrm{C}$; Kim et al., 1998) and cheese brining at $4^{\circ} \mathrm{C}$ for $12 \mathrm{~h}$ are effective in controlling listeria but not enterohemorrhagic E. coli, which are eliminated only by curd stretching at $80^{\circ} \mathrm{C}$ for $5 \mathrm{~min}$ (Spano et al., 2003). Incident microbes that are capable of surviving in cheese during storage reduce its shelf life.

Survivability of spoilage and pathogenic organisms during fresh Mozzarella cheese storage has yet to be characterized. Coppola et al. (1995) inferred that refrigeration temperature $\left(7^{\circ} \mathrm{C}\right)$ is sufficient to limit microbial survival but conducted the study over only $9 \mathrm{~d}$ of storage, which is insufficient to understand mechanisms that extend shelf life of fresh Mozzarella cheese. For soft-ripened cheeses, it was considered that unwanted bacteria do not survive beyond $60 \mathrm{~d}$ of storage, as exemplified by the 60-d rule for commercially sold cheeses (FDA, 2010a). However, this supposition was recently disproved by studies that found unwanted bacteria surviving even in semihard cheese (Cheddar) at $4 \mathrm{mo}$ in $4.5 \%$ salt (Schlesser et al., 2006; D'Amico et al., 2008). Fresh Mozzarella cheese has 2-fold higher moisture than Cheddar, is stored in water, has low salt in the curd, contains no added LAB, and has a shorter shelf life. Fresh Mozzarella cheese thus offers a model to understand the physicochemical conditions in soft cheeses that encourage bacterial survival.

In this study, we hypothesized that lack of salt promotes survival of unwanted bacteria in fresh Mozzarella cheese during extended storage, thereby altering its quality and safety. We determined the impact of salt on the microbial quality of fresh Mozzarella cheese and further, the ability of selected spoilage- or pathogenrelated bacteria to survive in fresh Mozzarella cheese.

\section{MATERIALS AND METHODS}

\section{Cheese Manufacture}

Cow's milk ( $\mathrm{pH} 6.6$ to 6.7) was obtained from Utah State University's Caine Dairy Research and Teaching Center (Wellsville) and HTST-pasteurized, as described earlier (McMahon et al., 2005). Manufacturing steps were adapted from a previous study on fresh Mozzarella cheese manufacture by direct acidification (Dave et al., 2003). Briefly, $680 \mathrm{~kg}$ of milk was heated to $35^{\circ} \mathrm{C}$ in Tetra Scherping horizontal cheese vats (Tetra Pak Cheese and Powder Systems Inc., Winsted, MN), acidified with white vinegar (final $\mathrm{pH} 5.5$ to 5.6), and set (20 min) using Maxiren double-strength rennet (DSM Food Specialties, Eaglesville, PA). Further, the curd was cut, allowed to heal $(5 \mathrm{~min})$, and stirred constantly (20 min). The curd was then transferred to a draining table to separate the curd from the whey, and dry stirred (60 min). The curd was separated into $10-\mathrm{kg}$ batches and processed in the cooker/stretcher, to give fresh Mozzarella cheese with 3 different salt treatments. The treatments were T1: no dry salting of curd before cooking, $3 \%$ salt in cooking brine, cooked at $60^{\circ} \mathrm{C}$, packaged in $1 \%$ brine; T2: no dry salting of curd before cooking, $3 \%$ salt in cooking brine, cooked at $60^{\circ} \mathrm{C}$, packaged dry; and T3: $1 \%$ salt added before cooking, $5 \%$ salt in cooking brine, cooked at $60^{\circ} \mathrm{C}$, packaged dry. The extruded cheese was cut into 25- to 30 -g cubes before packaging. Fresh Mozzarella cheese was either inoculated with bacteria or not (control), as described below.

\section{Proximate Analysis}

Proximate analysis was done on all cheeses at $5 \mathrm{~d}$ of storage. Moisture content was determined by weight loss using a microwave oven (CEM Corp., Indian Trail, $\mathrm{NC})$ at $70 \%$ power with an end-point setting of $<0.4$ mg weight change over $2 \mathrm{~s}$. Fat content was determined using a modified Babcock method (Richardson, 1985). Salt was measured by homogenizing grated cheese with distilled water for $4 \mathrm{~min}$ at $260 \mathrm{rpm}$ in a Stomacher 400 (Seward, West Sussex, UK). The slurry was filtered through a Whatman \#1 filter paper, and the filtrate was analyzed for sodium chloride by using a chloride analyzer (model 926, Corning, Medfield, MA). Cheese $\mathrm{pH}$ was measured using a glass electrode after stomaching $20 \mathrm{~g}$ of grated cheese with $10 \mathrm{~g}$ of distilled water for $1 \mathrm{~min}$ at $260 \mathrm{rpm}$. 


\section{Bacterial Addition}

Nonpathogenic E. coli (strain K12) and Enterococcus faecalis (strain ATCC 47077) were procured from the American Type Culture Collection (Manassas, VA), grown overnight in liquid media (tryptic soy medium and brain heart infusion broth, respectively) for 24 to $48 \mathrm{~h}$, and stored at $-70^{\circ} \mathrm{C}$ in nonfat dry milk containing $10 \%$ glycerol. Frozen cultures were thawed, grown twice for 18 to $24 \mathrm{~h}$, and shifted to $3^{\circ} \mathrm{C}$ at least $30 \mathrm{~min}$ before brining on the same day the cheese was made. After cooking, the cheese in cold 1\% (wt/wt) brine was moved to the laboratory and sufficient bacteria were added targeting a final population of $10^{4} \mathrm{cfu} / \mathrm{mL}$ in brine or dry cheese, as applicable. A suspension of bacterial cells $\left(10^{6}\right.$ to $\left.10^{7} \mathrm{cfu} / \mathrm{mL}\right)$ was prepared in sterile saline $(0.85 \% \mathrm{NaCl}$, wt/vol) before inoculation. For $\mathrm{T} 1$ cheeses, the bacterial suspension was added to the liquid portion of the brine-stored cheese. Each sample (25 to $30 \mathrm{~g}$ ) of the T2 and T3 cheeses was inoculated by adding the bacterial suspension to both surfaces of 2 cheese slices, which were then stacked and vacuumsealed together in a plastic bag for storage.

\section{Microbial Enumeration}

Bacteria were enumerated in both the cheese curd and brine separately, as applicable. The brine-stored cheese was packaged in closed containers with fresh liquid and stored at $4^{\circ} \mathrm{C}$, and the cheese and brine were sampled at $1 \mathrm{~d}$ (wk 0), 2, 4, 6, and 9 wk of storage for microbial analysis. Fresh Mozzarella cheese (1/4 to $1 / 3$ portion of curd) was blended (Seward) at $220 \mathrm{rpm}$ for 2 min along with $9 \times 0.85 \%$ (wt/vol) saline. The stomached suspension or the brine was further serial-diluted and plated on MacConkey's agar (for E. coli-added cheese; BD, Franklin Lakes, NJ) or KF streptococcal agar (for Ent. faecalis-added cheese; BD). Cheeses without added bacteria were analyzed at Great Basin Laboratory (Ogden, UT), where aerobic plate counts were done on plate count agar incubated at $30^{\circ} \mathrm{C}$ for 48 $\mathrm{h}$, coliforms on violet red bile agar incubated at $37^{\circ} \mathrm{C}$ for $48 \mathrm{~h}$, and psychrotrophic bacterial counts on plate count agar incubated at $8^{\circ} \mathrm{C}$ for $5 \mathrm{~d}$.

\section{Statistical Analysis}

Bacteria were enumerated in triplicate from the cheese samples that were selected at random over storage. Data from microbial enumeration were analyzed using a split-plot design in JMP software, version 7 (SAS Institute Inc., Cary, NC). Significance of results was inferred at $\alpha<0.05$.

\section{RESULTS AND DISCUSSION}

Fresh Mozzarella cheese was successfully made with 3 different salt treatments for microbial survival studies (Table 1). Microbial analyses of fresh Mozzarella cheese without added bacteria confirmed that coliforms and psychrophiles were absent from cheeses over 9 wk of storage (data not shown), suggesting that they may not be the chief spoilage agents. Aerobic plate counts in cheese without added bacteria did not change in 2 wk, but did increase by 1,000- to 10,000-fold at 4 wk in cheeses at all 3 salt levels and stayed at similar levels by 6 wk (Figure 1, top panel). From 6 to 9 wk, aerobic plate counts further increased by 0.5 to 2 decimal logs in the cheeses and brine, suggesting that bacteria continued to thrive at refrigeration temperatures. Incident aerobic bacteria appeared to grow significantly $(P<$ $0.05)$ faster in the high-salt dry cheese (T3) than in the brine-stored fresh Mozzarella cheese (T1). These observations suggest that spoilage of fresh Mozzarella cheese may be caused by unidentified cold-tolerant bacteria that need further characterization.

Aerobic bacterial counts increased between 2 and 4 wk of storage (Figure 1, top panel). Fresh Mozzarella cheese is typically expected to lose textural integrity and develop unacceptable flavor within this period, suggesting that incident bacteria grew slowly at refrigeration temperature. The types of bacteria, however, were unclear from the observed colonies. This implies that the conditions in fresh Mozzarella cheese $(\mathrm{pH}$ $5.5,60 \%$ moisture, 0.7 to $2 \%$ salt) do retard bacterial growth to some extent but are insufficient to prevent spoilage from bacterial outgrowth. Further analyses, such as $16 \mathrm{~S}$ ribosomal gene typing, are necessary to identify the proliferating bacterial species that cause cheese deterioration.

Table 1. Proximate analysis of fresh Mozzarella cheese $\mathrm{e}^{1}$

\begin{tabular}{|c|c|c|c|c|c|}
\hline Treatment & $\begin{array}{l}\text { Fat } \\
(\%)\end{array}$ & $\begin{array}{l}\text { Moisture } \\
(\%)\end{array}$ & $\mathrm{pH}$ & $\begin{array}{l}\text { Salt } \\
(\%)\end{array}$ & $\begin{array}{c}\text { Salt-in- } \\
\text { moisture (\%) }\end{array}$ \\
\hline No dry salt, $3 \%$ salt in cooker, packaged in $1 \%$ brine (T1) & $22.0 \pm 0.5$ & $60.3 \pm 0.1$ & $6.1 \pm 0.1$ & $0.5 \pm 0.05$ & 0.8 \\
\hline No dry salt, $3 \%$ salt in cooker, packaged dry (T2) & $21.0 \pm 0.5$ & $58.9 \pm 0.1$ & $5.8 \pm 0.1$ & $0.5 \pm 0.05$ & 0.8 \\
\hline
\end{tabular}

${ }^{1}$ Values are expressed as average \pm SD from duplicate sample assays. 

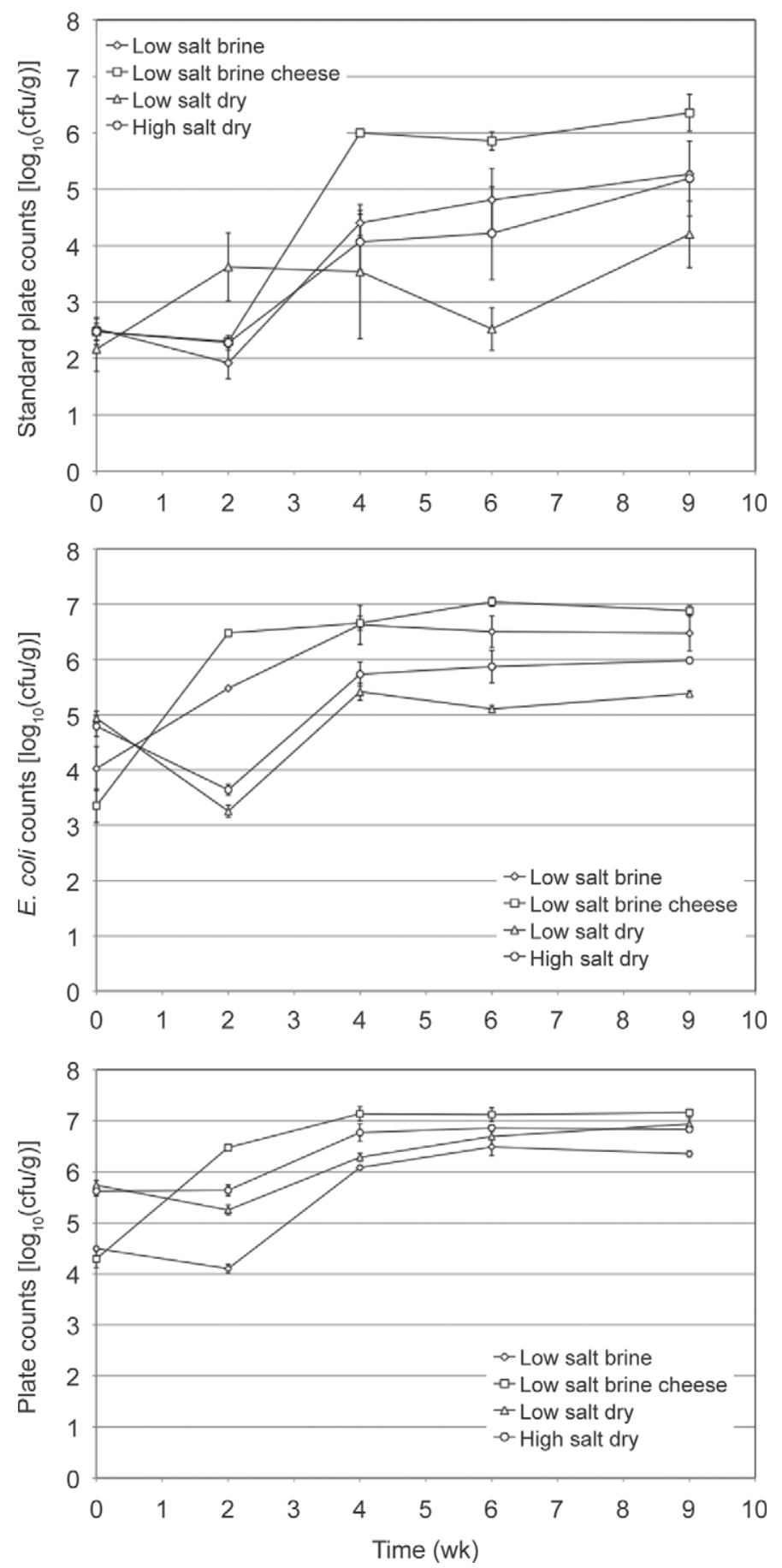

Figure 1. Aerobic plate counts of fresh Mozzarella cheeses and brine without added bacteria during storage in refrigeration (top panel), plate counts of Escherichia coli in E. coli-added cheeses during storage in refrigeration (middle panel), and plate counts of Enterococcus faecalis in Ent. faecalis-added cheeses during storage in refrigeration (bottom panel). Values plotted are averages of triplicate samples, with error bars showing standard deviations.
The impact of salt on indigenous bacteria in fresh Mozzarella cheese is unclear, considering that aerobic bacterial growth varied between the lower salt (T2) dry cheese and the dry fresh Mozzarella cheese containing $2 \%$ salt (T3). Although T2 cheese showed higher bacterial growth at $2 \mathrm{wk}$, overall higher bacterial counts were observed by 6 to 8 wk in T3 salt cheese (Figure 1, top panel). This observation may reflect different bacterial types surviving at the different salt and moisture contents.

Escherichia coli and Ent. faecalis were chosen as model microbes for survival studies because they represent the gram-negative and gram-positive bacterial groups, respectively, and cohabit fecal-contaminated water. Escherichia coli and Ent. faecalis added to fresh Mozzarella cheese grew by approximately 10- to 100-fold during 9 wk of refrigerated storage (Figure 1, middle and bottom panels). In the brine-stored fresh Mozzarella cheese, E. coli inoculated in the storage brine initially grew only in the brine and then further appeared to attach to curd (Figure 1, middle panel), as opposed to Ent. faecalis, which appeared to attach and thrive from initial brine inoculation only in curd, with minor population increases in brine over storage (Figure 1, bottom panel). Growth patterns of both added bacteria after 2 wk were similar, with an increase in numbers within the first $2 \mathrm{wk}$ in brine-stored cheese, as opposed to increases only between 2 and 4 wk in the dry cheeses. Addition of up to $2 \%$ salt in fresh Mozzarella cheese (T3) did not affect the growth of E. coli and Ent. faecalis.

Escherichia coli and Ent. faecalis survived similarly after $4 \mathrm{wk}$ of storage in curd (Figure 1, middle and bottom panels), suggesting that fecal contaminant bacteria may have similar survival patterns over longer storage times. As observed with aerobic bacterial counts, the higher salt content in curd appeared to have minimal impact on the growth of E. coli and Ent. faecalis during storage, suggesting that salt alone may not be sufficient to prevent bacterial outgrowth. Considering that lowmoisture part-skim Mozzarella cheese has a longer shelf life (at least 8 wk; Deeprose, 1996; Rondinini and Garzaroli, 1990) than fresh Mozzarella cheese, the presence of starter bacteria, lower moisture and $\mathrm{pH}$, and higher salt may cumulatively inhibit cheese spoilage attributable to incident bacteria from the curd contact surfaces and cooking and cooling brines.

Notably, in the brine-stored fresh Mozzarella cheese, E. coli and Ent. faecalis initially showed different trends of attachment to curd within $24 \mathrm{~h}$ (Figure 1). This observation suggests that different bacterial species may adhere to the curd surface and thrive at varying rates over storage and brings into question the target species of fresh Mozzarella cheese safety and spoilage. In 
addition, it is unclear whether the change in patterns of bacterial growth between brine and curd represent attachment as opposed to an extended stationary phase or cell death in brine. Considering that viable bacteria were always found in both brine and curd (Figure 1 ), the reduction in numbers or lack of growth in a particular portion - curd or brine - appears to be more likely due to transfer from brine to curd and not cell death. Differences in attachment of E. coli and Ent. faecalis suggest that, potentially, members of the coliform group require a longer time of contact to transfer from the water to curd, as opposed to bacteria related to Enterococcus. However, considering that we used only a single strain of each bacterial group, additional studies that tabulate variations in attachment of bacterial species, subspecies, and multiple strains to curd need to be conducted to provide a further comprehensive view of fresh Mozzarella cheese spoilage and safety.

Fresh Mozzarella cheese is a soft-style cheese that has a texture closely resembling other Mozzarella-type cheeses and must conform to the FDA-established standards of identity for Mozzarella cheese (FDA, 2011). However, fresh Mozzarella cheese is manufactured without LAB-driven acid production and therefore lacks the microbial barrier that most other semihard and hard cheeses possess. Additionally, fresh Mozzarella cheese has 55 to $60 \%$ moisture and may be stored in liquid, and thus, may possess higher water activity than other cheeses. Hence, we need to understand better the survivability of unknown incident bacteria during clean manufacturing conditions and also address the possibility of expected incident bacteria to survive post-incidence. Our study was designed to address these aspects by enumerating, in cold-stored fresh Mozzarella cheeses, the broader bacterial groups (aerobic bacteria, coliforms, and psychrophiles) usually suspected of spoilage or infection, and further, adding selected waterborne bacteria (nonpathogenic E. coli and Ent. faecalis) that may gain access to the product, to assess their survival. We also used different storage modes (brine-stored vs. dry) and salt levels (0.7 vs. $2 \%$ in dry cheeses) to understand their impact on limiting bacterial survival.

Salt level did not have a major impact on bacterial survival, as aerobic bacteria and added E. coli and Ent. faecalis survived and even grew to similar levels over $9 \mathrm{wk}$ in the respective cheeses (Figure 1). Storage conditions, however, did impact bacterial survival, wherein uncharacterized aerobic bacteria and added $E$. coli and Ent. faecalis grew to higher numbers by 100fold. Additionally, bacteria in the brine-stored cheeses reached similar levels in both curd and brine over 9 wk of storage, suggesting that wet storage promotes bacterial growth. Considering that bacteria need suffi- cient nutrients to meet their energetic demands during survival and growth, it is curious how bacteria managed to sustain in brine. Any minimal proteolysis at the curd surface and available lactose, short peptides, and whey proteins that leach out of the immersed curd may allow bacterial sustenance. We have shown in previous studies that even the fastidious LAB grow in a minimal chemically defined medium with low sugar and AA levels (Ganesan et al., 2007) and that the bacteria utilize peptides via ATP-dependent transport even when the cells are nonculturable. Further studies are needed to assess substrate availability and bacterial survival in cheese brines and thus decipher the metabolic mechanisms involved.

Coliform and psychrophilic bacteria were not detected over 9 wk of storage and enumeration, suggesting that these types of bacteria may not be incident in the fresh Mozzarella cheeses manufactured for this study. However, their absence must not be assumed in daily manufacture of fresh Mozzarella cheeses, as their incidence will cause early spoilage and may contribute to infection or toxicity. Indeed, in our study, added $E$. coli survived for 9 wk at $4^{\circ} \mathrm{C}$ and even grew in curd and brine (Figure 1). Incidence of unwanted bacteria caused $60 \%$ of product recalls in the United States within the last 3 mo (April to June 2012, as of June 21, 2012; FDA, 2012), of which coliforms alone contributed to nearly $33 \%$. Hence, minimizing bacterial incidence during manufacture of soft cheeses is critical for extending their shelf life and improving their safety.

Escherichia coli and Ent. faecalis, 2 species cohabiting fecal-contaminated water, attached to the cheese curd from brine at different rates and exhibited different growth dynamics in curd and brine (Figure 1). It is unclear why 2 species that occupy a common niche behave differently when confronted with a common nutrient surface. Different bacterial species may use different mechanisms to attach to the curd surface, which may require the development of an overarching intervention strategy that reduces their attachment to curd, as a supplement to milk pasteurization-derived bacterial destruction. By understanding the mechanisms that govern bacterial attraction to dairy product surfaces, we can strategically control and reduce their presence on food and equipment surfaces, and can extend fresh Mozzarella cheese shelf life.

\section{CONCLUSIONS}

Fresh Mozzarella cheese was manufactured in 3 different salt treatments to understand bacterial survival potential. Fresh Mozzarella cheese supported bacterial growth even under refrigerated storage, with minimal impact at up to $2 \%$ salt addition. Aerobic bacterial 
counts in fresh Mozzarella cheese increased in numbers between 2 and 4 wk of storage, but the cheeses without added bacteria did not contain any coliforms or psychrophiles. Escherichia coli and Ent. faecalis added to fresh Mozzarella cheese attached to curd at different rates, but eventually grew to similar numbers over $9 \mathrm{wk}$ of storage. Therefore, salt levels beyond $2 \%$ and additional mechanisms to prevent bacterial contamination and postincidence growth under refrigeration, such as including FDA-permitted antimicrobials, must be considered for extending fresh Mozzarella cheese shelf life.

\section{REFERENCES}

Anon., 1983. String cheese. North Eur. Dairy J. 49:145.

Bissonnette, N., R. A. Lachance, J. Goulet, M. Landgraf, and C. E. Park. 1980. Evidence of thermonuclease production by Bacillus spp. and enterococci in naturally contaminated cheese. Can. J. Microbiol. 26:722-725.

Bowen, D. A., and D. R. Henning. 1994. Coliform bacteria and Staphylococcus aureus in retail natural cheeses. J. Food Prot. 57:253-255.

Cabrini, A., and E. Neviani. 1983. Pseudomonas as the cause of bitter flavour and putrid smell on the surface of Mozzarella cheese. Latte 8:90-93.

Coppola, R., E. Sorrentino, L. Cinquanta, F. Rossi, M. Iorizzo, and L. Grazia. 1995. Shelf-life of Mozzarella cheese samples packaged without liquid and stored at different temperatures. Ital. J. Food Sci. $7: 351-359$.

D'Amico, D. J., M. J. Druart, and C. W. Donnelly. 2008. 60-day aging requirement does not ensure safety of surface-mold-ripened soft cheeses manufactured from raw or pasteurized milk when Listeria monocytogenes is introduced as a postprocessing contaminant. J. Food Prot. 71:1563-1571.

Dave, R. I., D. J. McMahon, C. J. Oberg, and J. R. Broadbent. 2003 Influence of coagulant level on proteolysis and functionality of mozzarella cheeses made using direct acidification. J. Dairy Sci. 86:114-126.

Deeprose, J. 1996. The string section. Dairy Ind. Int. 61:30-31.

Delbès, C., L. Ali-Mandjee, and M. C. Montel. 2007. Monitoring bacterial communities in raw milk and cheese by culture-dependent and -independent 16S rRNA gene-based analyses. Appl. Environ. Microbiol. 73:1882-1891.

el-Gazzar, F. E., and E. H. Marth. 1992. Salmonellae, salmonellosis, and dairy foods: A review. J. Dairy Sci. 75:2327-2343.

FDA (US Food and Drug Administration). 2009a. Torres Hillsdale Country Cheese LLC announces the recall of Oaxaca cheese due to possible Listeria monocytogenes contamination. Accessed June 21, 2012. http://www.fda.gov/ForConsumers/ConsumerUpdates/ ucm137183.htm

FDA (US Food and Drug Administration). 2009b. Warning on potentially contaminated cheese. Accessed May 16, 2011. http://www. fda.gov/ForConsumers/ConsumerUpdates/ucm129958.htm.

FDA (US Food and Drug Administration). 2010a. Title 21-Food and Drugs. Chapter I-Food and Drug Administration, Department of Health and Human Services. Subchapter B-Food for human consumption. Part 133-Cheeses and related cheese products. Subpart B-Requirements for specific standardized cheese and related products. 133.182 - Soft ripened cheeses. Department of Health and Human Services, Food and Drug Administration, Silver Spring, MD.

FDA (US Food and Drug Administration). 2010b. Azteca Linda Corp. recalls Queso Fresco and Queso Hebra because of possible risk of health. Accessed June 21, 2012. http://www.fda.gov/ForConsumers/ConsumerUpdates/ucm217902.htm.
FDA (US Food and Drug Administration). 2011. CFR - Code of Federal Regulations Title 21. Accessed June 21, 2012. http:// www.accessdata.fda.gov/scripts/cdrh/cfdocs/cfcfr/CFRSearch. $\mathrm{cfm} ?$ CFRPart $=133 \&$ showFR $=1$.

FDA (US Food and Drug Administration). 2012. Recalls, market withdrawals, \& safety alerts. Accessed June 21, 2012. http://www.fda. gov/Safety/Recalls/default.htm.

Fischer, R. and C. Megevand, inventors. 2006. Direct lactic acid set fresh mozzarella cheese. US Pat. Appl. No. 2006/0029714 A1.

Ganesan, B., M. R. Stuart, and B. C. Weimer. 2007. Carbohydrate starvation causes a metabolically active but nonculturable state in Lactococcus lactis. Appl. Environ. Microbiol. 73:2498-2512.

Kikuchi, M., Y. Matsumoto, S. Xue Mei, and S. Takao. 1996. Incidence and significance of thermoduric bacteria in farm milk supplies and commercial pasteurized milk. Anim. Sci. Technol. 67:265-272.

Kim, J., K. A. Schmidt, R. K. Phebus, and I. J. Jeon. 1998. Time and temperature of stretching as critical control points for Listeria monocytogenes during production of Mozzarella cheese. J. Food Prot. 61:116-118.

Koka, R., and B. C. Weimer. 2000. Isolation and characterization of a protease from Pseudomonas fluorescens RO98. J. Appl. Microbiol. 89:280-288

Koka, R. A., and B. C. Weimer. 2001. Influence of growth conditions on heat-stable phospholipase activity in Pseudomonas. J. Dairy Res. 68:109-116.

McMahon, D. J., B. Paulson, and C. J. Oberg. 2005. Influence of calcium, $\mathrm{pH}$, and moisture on protein matrix structure and functionality in direct-acidified nonfat Mozzarella cheese. J. Dairy Sci. 88:3754-3763.

Morea, M., F. Baruzzi, and P. S. Cocconcelli. 1999. Molecular and physiological characterization of dominant bacterial populations in traditional Mozzarella cheese processing. J. Appl. Microbiol. $87: 574-582$.

Pastorino, A. J., R. I. Dave, C. J. Oberg, and D. J. McMahon. 2002. Temperature effect on structure-opacity relationships of nonfat Mozzarella cheese. J. Dairy Sci. 85:2106-2113.

Rasooly, R., and P. M. Do. 2010. Shiga toxin Stx2 is heat-stable and not inactivated by pasteurization. Int. J. Food Microbiol. 136:290-294.

Rasooly, R., P. M. Do, S. M. Griffey, J. G. Vilches-Moure, and M. Friedman. 2010. Ingested shiga toxin 2 (Stx2) causes histopathological changes in kidney, spleen, and thymus tissues and mortality in mice. J. Agric. Food Chem. 58:9281-9286.

Richardson, G. H. 1985. Standard Methods for the Examination of Dairy Products. 15th ed. Am. Public Health Assoc., Washington, DC.

Rondinini, G., and C. Garzaroli. 1990. Microbiological aspects and spoilage phenomena of Mozzarella cheese produced by chemical acidification. Ind. Aliment. 29:329-334.

Schlesser, J. E., R. Gerdes, S. Ravishankar, K. Madsen, J. Mowbray, and A. Y. Teo. 2006. Survival of a five-strain cocktail of Escherichia coli $\mathrm{O} 157: \mathrm{H} 7$ during the 60-day aging period of Cheddar cheese made from unpasteurized milk. J. Food Prot. 69:990-998.

Spano, G., E. Goffredo, L. Beneduce, D. Tarantino, A. Dupuy, and S. Massa. 2003. Fate of Escherichia coli O157:H7 during the manufacture of mozzarella cheese. Lett. Appl. Microbiol. 36:73-76.

USDA. 1980. USDA specifications for mozzarella cheese. Accessed Sep. 18, 2012. http://www.ams.usda.gov/AMSv1.0/getfile?dDocName $=$ STELDEV3004561.

USDA. 2006. Per capita consumption of selected cheese varieties. Accessed Sep. 18, 2012. http://www.ers.usda.gov/data-products/ dairy-data.aspx.

Weeratna, R. D., and M. P. Doyle. 1991. Detection and production of verotoxin 1 of Escherichia coli O157:H7 in food. Appl. Environ. Microbiol. 57:2951-2955.

Zhang, W., and D. A. Sack. 2012. Progress and hurdles in the development of vaccines against enterotoxigenic Escherichia coli in humans. Expert Rev. Vaccines 11:677-694. 